\title{
The activities of transnational religious networks in the Northern Caspian region (on the example of protestants in Astrakhan region)
}

\author{
Mikhail Topchiev ${ }^{1 *}$, Dmitriy Chernichkin ${ }^{1}$, Vyacheslav Dryagalov ${ }^{1}$, and Anastasiya Demina ${ }^{1}$ \\ ${ }^{1}$ Astrakhan State University, 414056, Astrakhan, Russia
}

\begin{abstract}
This study examines the activities of Protestant religious denominations in the Northern Caspian region in the virtual space. The territory of the Northern Caspian region is represented by three regions: the Republic of Kalmyk, Astrakhan Region and the Republic of Kazakhstan (Atyrau Region). The Protestant associations are most concentrated in Astrakhan Region; therefore, in this case it is more appropriate to consider this territory. The main goal of the work is to identify the specifics of Protestant network associations in Astrakhan region, as well as the analysis of their proselytistic activity. The main methodology of the study is the content analysis of regional sites of Protestant religious associations, and groups in social networks, as well as the analysis of expert interviews with the pastor of one of the Protestant churches.
\end{abstract}

\section{Introduction}

Protestantism in Russia is one of the major representatives of the religious space, defining the confessional "image" of the country. Today, there are approximately 3 million Protestants and about 10,000 Protestant parishes in the country (see Lunkin, 2014).

An important feature of Protestantism, which distinguishes it from other religious systems traditional for Russia (Orthodoxy, Islam, Buddhism), is its flexibility and adaptation to the processes of universal globalization and virtualization. It builds universal mechanisms for the inclusion of the individual in the community of believers, regardless of their ethnicity and formal relationship with other religious traditions. Studying the religious dialogue of Russian Protestants as one of the most important forms of functioning of Protestant communities, we can distinguish several areas of research: this is philological discourse in a religious environment (e.g. Fedorova, 2014; Bobyreva, 2007; Bobyreva, 2013; Diachkova, 2013), inter communal interaction and relations between Protestant denominations and the state (e.g. Zhelnovakova, 2013; Gavrilov \& Gavrilov, 2015; Itzkovich, 2014), communication between God and man (Smirnov, 2005; Ambartsumov, 2017; Dvorkin, 2014).

Today, religion still covers all aspects of human life. Modern society more than ever needs well-established values. Along with the influence of the Russian Orthodox Church in

\footnotetext{
*Corresponding author: ceo.gfn@gmail.com
} 
the post-Soviet space, other forms of religion are actively developing. In this article, we observe the activities of Protestant associations that are active in the Northern Caspian region, territorially covering the Republic of Kalmyk, Astrakhan Region and the Republic of Kazakhstan (Atyrau Region) with both a real flock and a virtual one.

\section{Research methodology}

The research methodology is presented primarily by content analysis of chat groups in social networks VKontakte and Odnoklassniki that are the most popular in Russia. It was conducted from March 14, 2019 to June 23, 2019. The sample is made on the religious orientation of these groups. It is represented by 16 groups in the social network VKontakte and 4 groups in the social network Odnoklassniki. The choice of analysis units was made on the basis of their religious affiliation to the subject of the study. Namely, the mention in the records of a group of various Protestant denominations, as well as certain key words: God, faith, religion, Christians, Christ, Protestants, and brothers. As a result, 223 entries on the wall of communities in the social network VKontakte and 34 entries in the social network Odnoklassniki, published in the period from 03/14/2019 to 06/23/2019, were analyzed. Additional information about the activities of Protestant associations was obtained through expert interview with pastor of the Seventh Day Adventist Church.

Based on the analysis of public events held by Protestant religious associations officially registered in the studied region, studying the activity of virtual religious associations of Protestants in various popular social networks, as well as the frequency and content of published records in these virtual communities, it can be concluded that in the Northern Caspian region officially registered are 20 registered Protestant associations of various denominations. It is not possible to specify the total number of parishioners due to the fact that the pastors of the communities themselves are not always aware of the number of parishioners of their churches, as well as the absence of a fixed number of subscribers of the virtual communities of these churches.

\section{The place of Protestantism in the confessional landscape of the Northern Caspian}

The confessional composition on the territory of the Northern Caspian region is represented by three largest denominations: Buddhism (the Republic of Kalmyk), Islam (the Republic of Kazakhstan) and Orthodox Christianity (Astrakhan Region). Due to the fact that the Republic of Kalmyk and the Republic of Kazakhstan are mono-ethnic and monoconfessional, in this study it would be more appropriate to consider Astrakhan region because this region has historically been multicultural and multi-confessional. For a long time the representatives of various cultures, nations and religions lived together on this territory. Currently, there are about 30 confessions in the region, the largest of which are Orthodoxy, Islam, and Buddhism.

Mostly Pentecostals (ten associations) and Baptists (four associations) represent Protestant denominations. In addition to them, there are Lutherans, Adventists, NeoPentecostal (moderate charismatics), the Evangelical Christian Missionary Union, and the International Christian Interfaith Movement of the XXI century in the city and region. The last two ones were formed in the end of 90's and early 2000s in Russia and have a rather extensive network of churches throughout the country (see fig. 1). 


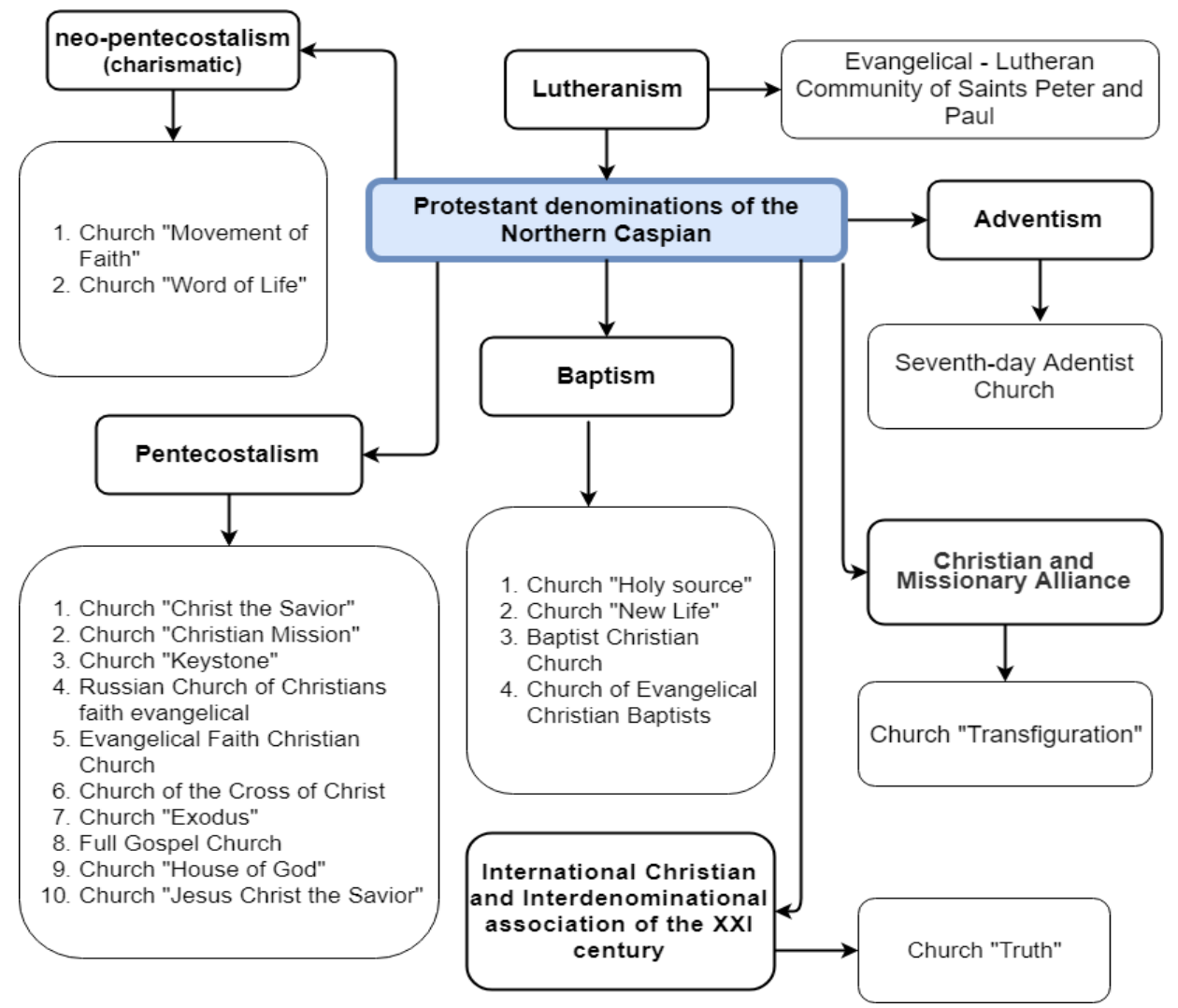

Fig. 1. Protestant denominations of the Northern Caspian

Moderators representing these denominations in the virtual space duplicate most of the information about the activities and public work carried out in their groups in various social networks. Similar online communities exist in almost every Protestant church. Therefore, during the preparation of this article, the authors of the study for several months studied the activity of several Protestant associations in social networks, in order to analyze their religious and social activities in the framework of the studied region.

\section{Analysis of the activities of the protestant denominations in the territory of astrakhan region}

One of the most common Protestant denominations in the Northern Caspian is Pentecostalism. Pentecostal Christians are Protestant Christians who believe that the manifestations of the Holy Spirit are alive, accessible and experienced by modern Christians. In some sources, the Pentecostals can be described as "charismatics." The term "Pentecostal" comes from the New Testament experience of early Christians on the day of Pentecost, when "... the Holy Spirit was poured out on the disciples, and the tongues of fire fell on their heads ..." (Acts 2: 1-4.). Their worship can be characterized by a lively and emotional expression of worship with great spontaneity. (see Christian and Missionary Alliance). Today there are more than 279 million people in the world who identify themselves with this religious movement. Examples of Pentecostal denominations include: the Assembly of God, the Church of God, the Church of the Full Gospel, the Church of Pentecostal Unity, etc. (Bobyreva, 2007). 
In Russia, the number of Pentecostal denominations, as well as the number of parishioners is difficult to calculate, but it is worth noting that in our country Pentecostalism is mainly represented by three major associations: the Russian Church of Evangelical Christian Christians, the Russian Evangelical Christian Union of Christians and the united Church of Evangelical Christian Christians. In addition, there are separate independent churches and associations. As for the Astrakhan region, then, as of 2019, 10 churches and associations of this denomination are registered in the region (see Department...). The exact number of Pentecostals in the region is difficult to determine, but based on the fact that the overwhelming majority of parishioners who are members of the Pentecostal Internet communities in the Astrakhan region are parishioners of these churches, it can be conditionally determined that their number will vary within 1,150 people.

Among the Pentecostal churches, one of the most numerous in the city of Astrakhan in terms of the number of parishioners is the "Church of Christ the Savior." Analyzing their activities in the virtual space, it is worth saying that their community is also the most numerous (314 subscribers), congregations meet twice a week: on Thursday and Sunday. On the basis of the content analysis of the records published in the public of this community, the authors of the article identified the main directions of their activities:

- Conducting prayer meetings (they have a permanent location, unlike other Pentecostal churches);

- Active work with young people (holding separate youth ministries, concerts, training in various folk crafts, field trips, joint campaigns, trips to All-Russian religious conferences, etc.);

- $\quad$ Charity (helping children from orphanages, building and serving in a rehabilitation center for alcohol addicts);

- Creative activity (organization of entertainment events, most often inside the church, by the parishioners).

In addition, Russian and foreign lecturers, pastors, public figures from other Pentecostal churches, who hold meetings with both mature parishioners and young people, are sometimes invited to attend services. Since July 2018, they have launched a channel on YouTube video hosting, where with a certain frequency they publish various reports on the activities of the Church of Christ the Savior, videos from services and lectures, as well as an annual review of their public activities (see Church of Christ the Savior).

Another numerous denomination on the territory of the studied region is Baptism. (Mitrokhin, 1997). The name "Baptism" since 1644 applies to those who claim that baptism should occur only at a conscious age through complete immersion in water (the word "Baptist" comes from the Greek $\beta \alpha \pi \tau \omega$ - "immersed in water"). This method is recognized by them as the only correct way to perform the ordinance of baptism (as opposed to pouring over or sprinkling), which is indicated in the New Testament. Baptists generally recognize two ordinances: baptism and the sacrament (Lunkin, 2007). The very same denomination was finally formed by the beginning of the XVII century, based on the teachings of radical English Puritans (see Lunkin, 2014).

Baptists insist that the main authority under Christ belongs to the local community of believers, which accepts and excludes members, calls and ordains pastors and manages their common life in accordance with what it understands as the wisdom of Christ. These communities are united in joint bodies - regional associations, state conventions and national conventions to which they send their delegates or envoys. Larger organizations, as a rule, have no control or authority over the local church; they exist only for the realization of the common interests of local churches. In Russia, the first Baptist communities appeared in the middle of the XIX century, and today, according to the estimates of the 
Russian researcher L.N. Mitrokhin in the country has approximately 2,000 communities that cover more than 250 thousand people (see Fedorova, 2014).

As for the territory of the Northern Caspian, the largest Baptist church is also located in the city of Astrakhan, which belongs to the Eurasian Federation of Unions of Evangelical Christian Baptists - the New Life Church. Like the Pentecostal church described above, this church has its own group on the social network VKontakte (263 subscribers). Based on the data that moderators of this group actively publish, it is possible to determine the main activities of the parishioners and church leaders:

- General sermons, youth ministrations;

- Charitable trips to orphanages;

- Involvement of young people in the activities (organization of children's parties, yard clubs, sports games, etc.)

- Organizing and conducting concerts and song evenings by parishioners within the walls of the church.

In addition to their activities within the walls of the church, Baptists are actively working in the virtual space, daily publishing various entries devoted to the reading of sacred writings, ceremonies, lectures and seminars, etc. Permanent work both inside and outside the church allowed them in February 2018 to obtain permission from regional authorities to receive the building in Astrakhan as the property to house the second house of worship (see Order...). This event suggests that the community is constantly expanding, attracting new supporters to its community.

Among the various denominations that conduct their activities on the territory of the studied region, it is worth mentioning another association that emerged in Russia at the turn of the 90s - 00s - the Gospel Christian Missionary Union (EXMS). The EXMS is one of the youngest Protestant organizations in Russia, which possesses a fundamentally new, in the opinion of the leaders of this union, the ideology of the evangelical movement, which took shape during the 1990s. The main ideologue of the union was the pastoral team of the missionary church in Krasnodar and, above all, its first president, the pastor of the Krasnodar church, Semyon Borodin, who comes from the Council of Churches (initiative) community. The missionary churches of the Union were almost all created in the 90 s, their age does not exceed 8-9 years. The new churches of the Union perceive themselves to be the heirs of the evangelical ideology of I. S. Prokhanov, the leader of evangelical Christians in the early twentieth century. The main components of this ideology is an energetic mission, using all the acceptable methods of work that are constantly changing, in accordance with the conditions and culture of the people among whom the preaching is conducted (Dvorkin, 2014). In the Astrakhan region, the representative of this union is the Church of the Transfiguration. The church building is located in the city, is completely closed to strangers, is open only to the congregation of the community, therefore it is not possible to conduct any form of survey. This association is not active in any social network; on the official website of the union there is also no information about their activities.

\section{Social work}

In addition to religious activities, almost all Protestant communities are active in social work. Due to the fact that the majority of Protestant communities are rather closed, it is not possible to collect objective information about the social activities of all communities. We were able to interview only one pastor of the Seventh Day Adventist Church. In the interview process, the informant spoke in detail about the activities of both representatives of state structures and other Protestant communities.

Answering the question "Does your church lead some kind of social work?" the informant noted that their church was working in various areas. "We work with the 
Department of the Penitentiary Service, we work with medical institutions, distribute newspapers monthly, we help the poor. Every week we have a collection station for the poor, where we get clothes; people bring them and we distribute them, as second-hand goods are free for the poor... we invite people; people come, choose clothes, sometimes we help people in need with products. We call this "social ministry." Now we are planning to open a social center so that there will be organized help, free haircuts, dining and so on. Once a week, we do a kind of ministry for poor people ... we already have a room. Now it happens more during and after the service, the needy come, knowing that they can be of help here, especially on the eve of the winter period, when warm clothes are needed..." (Alexander, 44, pastor of the Seventh Day Adventist Church, Astrakhan)

As for the issues of integration into the confessional landscape of the region, the informant responded that there are no conflicts on religious grounds, moreover, he noted that several parishioners in the church are in interfaith marriages: "...there are marriages with the Orthodox, there are ones with the Muslims..." (Alexander, 44, pastor of the Seventh Day Adventist Church, Astrakhan)

\section{Conclusion}

Thus, in the post-Soviet space of the Northern Caspian region, a whole network of Protestant associations was formed. It took a stable position due to their ability to transform in a constantly changing society, despite the fact that a few decades ago, Protestants, by the will of the authorities, were subjected to brutal persecution. Therefore, many communities were forced to abandon active missionary work and replenish their communities at the expense of young people.

Dew to the underrepresentation of Protestants in the elite of society (in prestigious areas of state and municipal government, production, culture, and business), the low activity of Protestant associations and communities in solving global religious issues of the state has been noted. The spiritual and moral potential of Astrakhan Protestantism and its growing social activity suggest that its constructive role in Russian society will increase noticeably in the near future.

\section{Implications and limitations as well as future research}

At the present moment, the authors of the article fix the gradual growth of the religious segment of the virtual space, and each religious institution forms its own system of unique services, some of which are adapted only for the needs of Internet users. The most active are religious associations and denominations conducting their proselytistic activities on the territory of the Russian Federation. In this regard, this segment of religious activity is becoming increasingly relevant to study, and therefore requires further research.

The article was supported by the Russian Foundation for Basic Research, Project No. 17-33-01095 "a2": «Transnational religious networks and confessional security».

\section{References}

1. N.I. Ambartsumov, Charismatic communities of St. Petersburg: history, church organization, features of dogma and social service, Christian reading, 5, 232-239 (2017)

2. E.V. Bobyreva, Religious discource: values, genres, strategies (Volgograd state pedagogical University, Volgograd, 2007) 
3. E.V. Bobyreva, Spheres of functioning and peculiarities of religious discource, World of Science, Culture and Education, 5, 296-298 (2013)

4. Church of Christ the Savior, information on: https://vk.com/club3132741

5. Church of Evangelical Christian-Baptist in Astrakhan "New Life", information on: https://vk.com/novaya_zhizn

6. Christian and Missionary Alliance, information on: http://exmc.ru/

7. N.A. Diachkova, Religious and secular discource: problems of communication, Bulletin of the Chelyabinsk State University, 37(328), 34-36 (2013)

8. A.L Dvorkin, Sect. Totalitarian sects, Systematic research experience, Nizhny Novgorod, 559-598 (2014)

9. M.V. Fedorova, Religious communication: essence and peculiarity of modern state, Science Time, 4(4), 230-240 (2014)

10. O.F., Gavrilov, E.O. Gavrilov, Peculiarities of religious communication in Russia, Bulletin of the Kemerovo State University, 1-2(61), 198-202 (2015)

11. Global Christianity A Report on the Size and Distribution of the World's Christian Population, information on: http://www.pewforum.org/2011/12/19/global-christianitymovements-and-denominations/

12. L.I. Grigorieva, Baptism, Enisey Encyclopedic Dictionary, Krasnoyarsk: the Russian Encyclopedia Association, 59 (1998)

13. International Christian and Interdenominational association of the XXI century, information on: http://iicm.ru/dokumenty/

14. T.V. Itzkovich, Multilingualism in the sphere of religious communication, Acute Problems of Literary Studies and Pedagogical Linguistics, 16, 185-188 (2014)

15. R.N. Lunkin, Pentecost and Charisma: Unity in Diversity, Religion and Law, 2(41), 31 33 (2007)

16. R.N. Lunkin, Russian Protestantism: Evangelical Christians as a New Social Phenomenon, Modern Europe, 3(59), 133-143 (2014)

17. L.N. Baptism: history and modernity (philosophical and sociological essays), St. Petersburg: Russian Christian Academy of Humanities, 44 (1997)

18. Order of the Administration of the MO "Astrakhan" №62, information on: https://vk.com/novaya_zhizn?z=photo-4794592_456239585\%2Falbum4794592_00\%2Frev

19. M. Yu. Smirnov, Reformation and Protestantism: Dictionary, St. Petersburg: Publishing house of St. Petersburg State University (2005)

20. Department of the Ministry of Justice of the Russian Federation in the Astrakhan region, information on: http://to30.minjust.ru/ru/rezultaty-proverok-nekommercheskihorganizaciy-provedennyh-v-2012-godu

21.Ya.Ya. Vins, Our Baptist Principles, information on: http://rusbaptist.stunda.org/vins.html

22. M.F. Zhelnovakova, The system of external religious communication in Russia, Modern Problems of Science and Education, 3, (2013). 